\title{
EFEKTIFITAS TERAPI NERS SPESIALIS TERHADAP ANSIETAS DAN KEMAMPUAN PASIEN STROKE DALAM MERUBAH PIKIRAN NEGATIF DI RS HERMINA JATINEGARA
}

\author{
Sri Laela ${ }^{1}$, Ening Wahyuni ${ }^{2}$ \\ 1. Dosen Akademi Keperawatan Manggala Husada \\ 2. Dosen Akademi Keperawatan Manggala Husada \\ Email:srilaela13@gmail.com
}

\begin{abstract}
Abstrak
Pasien stroke yang di rawat di rumah sakit beresiko mengalami ansietas, hal ini dikarenakan pasien mengalami gangguan fisik yang mengakibatkan terganggunya aktifitas dalam jangka waktu yang lama. Masalah emosi setelah stroke membuat pasien mudah tersinggung, menangis dan marah tanpa alasan yang jelas. Riskesdas (2013) menyebutkan bahwa prevalensi penyakit stroke di Indonesia meningkat seiring bertambahnya umur dan sekitar delapan per seribu penduduk atau 0,8\% mengalami stroke Tujuan penelitian ini mengidentifikasi pengaruh terapi kognitif dan psikoedukasi keluarga terhadap ansietas dan kemampuan pasien stroke dalam merubah pikiran negatif. Metodologi yang digunakan quasi-experiment one group with pretest - posttest design dengan metode consecutive sampling. Responden berjumlah 27 pasien stroke di RS Hermina Jatinegara. Penelitian dilakukan Agustus sampai Desember 2018. Kuesioner yang di gunakan Hospital Anxiety Depression Scale (HADS) dan kuesioner Automatic Thought Questionare (ATQ). Hasil penelitian menunjukan bahwa tindakan keperawatan Ners, terapi kognitif dan psikoedukasi keluarga signifikan menurunkan ansietas dan meningkatkan kemampuan pasien stroke dalam merubah pikiran negatif. Kombinasi terapi kognitif dan psikoedukasi keluarga di rekomendasikan untuk mengatasi ansietas dan meningkatkan kemampuan pasien stroke dalam merubah pikiran negatif.
\end{abstract}

Kata kunci: Ansietas, psikoedukasi keluarga, terapi kognitif

\begin{abstract}
Stroke patients who are treated in the hospitals are at risk of experiencing anxiety, its because patients have physical disorders that result in disruption of activities for a long time. Emotional problems after a stroke make the patient irritable, cry and angry for no apparent reason. Riskesdas (2013) states that the prevalence of stroke in Indonesia increases with increasing age and around eight per thousand population or $0.8 \%$ experience stroke. The purpose of this study identified the influence of cognitive therapy and family psychoeducation on anxiety and the ability of stroke patients to change negative thoughts. The methodology was used quasi-experiment of one group with pretest - posttest design with consecutive sampling method. The respondents were 27 patients at Hermina Hospital Jatinegara. The study was conducted from August untill December 2018. The questionnaire was used the Hospital Anxiety Depression Scale (HADS) and the Automatic Thought Questionnaire (ATQ) questionnaire. The results showed that nurses intervention, cognitive therapy and family psychoeducation significantly reduced anxiety and improved the ability of stroke patients to change negative thoughts. The combination of cognitive therapy and family psychoeducation is recommended to overcome anxiety and improve the ability of stroke patients to change negative thoughts.
\end{abstract}

Keywords: anxiety, cognitive therapy, family psychoeducation

\section{Pendahuluan}

Stroke adalah penyakit atau gangguan fungsional otak berupa kelumpuhan saraf (deficit neurologis) akibat terhambatnya aliran darah ke otak (Junaidi, 2011). Stroke juga didefinisikan sebagai kelainan fungsi otak yang timbul mendadak, disebabkan karena terjadi gangguan peredaran darah otak dan dapat terjadi pada siapa saja dan kapan saja (Mustaqin, 2008). Stroke merupakan penyebab utama kecacatan 
danmenjadi penyebab ketiga kematian di dunia setelah jantung dan kanker.

WHO (2012) menyebutkan bahwa kematianakibat stroke sebesar $51 \%$ di seluruh dunia disebabkan oleh tekanan darahtinggi. Selain itu, diperkirakan sebesar $16 \%$ kematian stroke disebabkantingginya kadar glukosa darah dalam tubuh. Di dunia 15 juta orang menderita stroke setiap tahunnya(Elkind, 2010).

Data nasional di Indonesia menunjukkan stroke menjadi penyebab kematian tertinggi yaitu 15,4\% (Soertidewi, 2011). Riskesdas (2013) menyebutkan bahwa prevalensi penyakit stroke dilndonesia meningkat seiring bertambahnya umur dan sekitar delapan per seribu penduduk atau $0,8 \%$ mengalami stroke.

(Kemenkes, 2013) menyatakan bahwa prevalensi kasus stroke di Indonesia sebesar 7,0 per mill dan 12,1 per mill untuk yang terdiagnosis memiliki gejala stroke. Dari total jumlah penderita stroke di Indonesia, sekitar 2,5 \% atau 250 ribu orang meninggal dunia dan sisanya cacat ringan maupun berat sehingga tahun 2020 mendatang diperkirakan 7,6 juta orang akan meninggal karena stroke.

Kesembuhan pasien stroke tergantung pada beberapa elemen yaitu jumlah dan lokasi otak yang rusak, kesehatan umum pasien yang bersangkutan, sifat-sifat (personality) dan kondisi emosional pasien. Demikian juga dukungan dari keluarga dan teman - teman serta yang terpenting adalah pengobatan yang diterimanya (Pudiastuti, 2011). Hal yang paling ditakuti oleh penderita stroke adalah bahwa hampir selalu penderita yang diserang stroke akan mengalami kecacatan, sehingga dapat mengubah seseorang yang tadinya kuat dan tampak tidak kenal takut menjadi lemah dan selalu bergantung pada bantuan orang lain. Menurut Sharley (2003) dalam Sembiring (2010) menyebutkan bahwa dari sisi psikologi, stroke dapat membuat penderita merasa rendah diri dan tidak berguna akibat kecacatan.

Kecacatan akibatstroke mengakibatkan pasien merasa cemas, sehingga mempengaruhi proses pengobatan dan rehabilitasi. Dalam hal ini konsekuensi sosial dan emosi pada cedera otak membutuhkan perhatian ekstra dalam proses rehabilitasi, salah satunya dengan menurunkan tingkat kecemasan dan mengubah perasaan tertekan karena mengalami perubahan traumatis dalam kualitas hidupnya.

Videbeck (2011) menyatakan bahwa stressor kronis seperti yang disebabkan oleh masalah kesehatan dapatmenimbulkan gangguan ansietas. Gejala ansietas terjadi pada $70 \%$ pasien yang mengalami masalah fisik.Kaplan dan Saddock (2009)mengungkapkan bahwa pasien stroke memiliki episode ansietas. 
Ansietas merupakan gangguan psikososial yang sering terjadi pada setiap individu (Videbeck, 2011). Ansietas adalah perasaan ketakutan yang menyeluruh, tidak menyenangkan, seringkali disertai gejala otonomik seperti nyeri kepala, jantung berdebar, gangguan lambung ringan maupun berkeringat. Ansietas juga merupakan respon terhadap situasi tertentu yang mengancam, dan merupakan hal normal yang terjadi menyertai perkembangan, perubahan, pengalaman baru atau yang belum pernah dilakukan, serta dalam menentukan identitas diri dan arti hidup (Sadock \& Sadock, 2009).

Terapi individu yang efektif dalam mengatasi ansietas adalah Cognitive Therapy (CT), Behavior Therapy (BT), Thought stopping, dan Cognitive Behavior Therapy (Varcolis, 2006). Townsend (2009) menjelaskan bahwaterapi kognitif juga dapat membantu individu mengatasi respon ansietasakibat yang ditimbulkan oleh distorsi pikiran negatif. Hasil penelitian Sarfika (2012) menyebutkan bahwa terapi kognitif secara bermakna mampu menurunkan ansietas dan mengontrol pikiran negatif pada pasien diabetes melitus.

Pasien stroke merupakan individu yang rentan dengan berbagai masalah,tidak hanya masalah fisik tapi juga masalah mental, sehingga sangatdiperlukan support sistem yang adekuat untuk dapat menghadapi penyakittersebut. Menurut Friedman (2010) salah satu support sytem yang dapatdiberdayakan adalah keluarga, karena keluarga adalah bagian yang tidakterpisahkan dari individu. Keluarga merupakan bagian dari manusia yangsetiap hari selalu berhubungan dengan individu. Keluarga merupakan bagianpenting manakala seseorang mengalami berbagai macam persoalan, salahsatunya adalah gangguan kesehatan yang dapat berupa penyakit.

Psikoedukasi adalah salah satu bentuk terapi keperawatan kesehatan jiwa keluarga dengan cara pemberian informasi dan edukasi melalui komunikasi yang teraupetik. Terapi psikoedukasi keluarga menjadi terapi yang sangat tepat dilakukan pada keluarga dengan stroke yang memiliki masalah ansietas. Tujuan terapi ini adalah menurunkan intensitas emosi seperti ansietas dalam keluarga sampai pada tingkatan yang rendah dengan sebelumnya dilakukan manajemen terhadap pengetahuan tentang perawatan stroke sehingga dapat meningkatkan pencapaian tujuan melalui sumber kekuatan dalam keluarga itu sendiri.

Terapi ini dirancang terutama untuk meningkatkan pengetahuan keluarga tentang penyakit mengajarkan tehnik yang dapat membantu keluarga untuk mengetahui gejala gejala penyimpangan perilaku, serta peningkatan dukungan bagi 
anggota keluarga itu sendiri (Stuart \& Sundeen, 2005).

Hasil penelitian yang dilakukan oleh Nurbani (2009) menyebutkan bahwa terapi psikoedukasi keluarga mampu mengurangi ansietas keluarga dalam merawat pasien stroke. Berdasarkan hasil penelitian tersebut terbukti bahwa terapi psikoedukasi keluarga sangat dibutuhkan pada saat menangani masalah psikososial keluarga akibat penyakit fisik anggota keluarganya.

Dari data yang diperoleh RS Hermina Jatinegara terdapat 187 orang menderita stroke pada tahun 2016, yang terdiri dari 154 kasus (82\%) stroke non hemoragik dan 33 kasus (18\%) stroke hemoragik. Hasil pengamatan pada pasien stroke didapatkan bahwa pasien yang dirawat di rumah sakit sering mengalami stress dan masalah psikologis yang berkaitan dengan penyakitnya yang dapat mengakibatkan pasien mengalami kecemasan.Gejala cemas yang ditunjukkan oleh pasien antara lain pasien mengeluh cemas dan takut, gangguan tidur, kehilangan nafsu makan, pasien merasa sesak, peningkatan denyut jantung dan tekanan darah, pasien tampak gelisah, muka tegang, mudah berkeringat, sikap menolak, berbicara kasar dan kurang konsentrasi.

Hasil wawancara peneliti dengan perawat ruangan (2018, 09 Juli ) didapatkan informasi bahwa perawat menemukan adanya tanda - tanda ansietas pada pasien dan keluarga yang mengalami stroke, pasien banyak bertanya terkait proses pengobatan yang di berikan di rumah sakit. Perawat mengatakan bahwa asuhan keperawatan terhadap pasien stroke masih berfokus pada diagnosa fisik bukan diagnosa psikososial. Diagnosis keperawatan yang ditegakkan, seperti gangguan perfusi jaringan cerebral dan gangguan mobilitas fisik. Diagnosis ansietas memang sudah ditegakkan, namun tindakan yang dilakukan hanya berupa pendidikan kesehatan tentang stroke. Perawat menjelaskan bahwa perawatan pasien stroke di ruangan sudah melibatkan keluarga.Perawat juga mengatakan bahwa belum ada standar asuhan keperawatan ansietas di ruang perawatan.

Berdasarkan data tersebut peneliti tertarik untuk melakukan penelitian tentang "Pengaruh terapi kognitif dan psikoedukasi keluarga terhadap ansietas dan kemampuan pasien stroke dalam merubah pikiran negatif di RS Hermina Jatinegara.

\section{Metode Penelitian}

Penelitian ini menggunakan rancangan quasi-experiment one group with pre test post test design, yaitu observasi dilakukan sebelumperlakuan dan sesudah perlakuan tanpa menggunakan kelompok kontrol.Pendekatan pret-post test without 
control group design digunakan untuk melihat perubahan ansietas pada pasien stroke sebelum dan sesudah terapi kognitif dan psikoedukasi keluarga. Jumlah sampel 27 responden. Total waktu penelitian12 minggu, yaitu mulai Oktober sampai Desember 2018. Instrumen yang digunakan dalam penelitian ini adalah kuesioner HADS (Hospital Anxiety Depression Scale) dan instrumen Automatic Thought Quesionare (ATQ).

\section{Hasil}

Karakteristik usia rata-rata pasien stroke yang di rawat di RS Hermina Jatinegara berusia 56,5 tahun dengan usia termuda 54 tahun dan usia tertua 65 tahun.Karakteristik usia pasien stroke dapat di lihat pada tabel 1

Tabel 1. Karakteristik Usia Pasien Stroke di RS Hermina Jatinegara $(n=27)$

\begin{tabular}{lcccccc}
\hline Variabel & $\mathbf{N}$ & Mean & SD & Min & Max & P.val \\
\hline Usia & 27 & 56,5 & 6,765 & 54 & 65 & $\mathbf{0 , 5 1 4}$ \\
\hline
\end{tabular}

Karakteristik mahasiswa berdasarkan jenis kelamin, pendapatan keluarga dan riwayat ansietas di keluarga dilakukan dengan menggunakan distribusi frekuensi yang hasilnya dapat dilihat pada tabel 2.

Berdasarkan analisis tabel 2. didapatkan bahwa jenis kelamin pasien stroke di RS Hermina jatinegara paling banyak adalah perempuansebanyak 14 orang $(51,8 \%)$. Pendapatan keluarga paling banyak kurang dari 3 juta(70,3\%). Riwayat ansietas di keluarga paling banyak di alami pasien stroke adalah sebesar 27 orang (100\%).

Tabel 2. Karakteristik Jenis kelamin, pendapatan keluarga dan riwayat ansietas di keluarga pada pasien stroke di RS Hermina Jatinegara $(n=27)$

\begin{tabular}{|c|c|c|c|}
\hline \multirow[t]{2}{*}{ Karakteristik } & \multicolumn{2}{|c|}{$\begin{array}{r}\text { Jumlah } \\
(n=27)\end{array}$} & \multirow[t]{2}{*}{ P. Value } \\
\hline & $\mathbf{N}$ & $\%$ & \\
\hline Jenis kelamin & & & 0,267 \\
\hline 1. Perempuan & 14 & 51,8 & \\
\hline 2. Laki-laki & 13 & 48,2 & \\
\hline Total & 27 & 100 & \\
\hline Pendapatan keluarga & & & 0,469 \\
\hline 1. $<3$ juta & 19 & 70,3 & \\
\hline 2. > 3 juta & 8 & 29,6 & \\
\hline Total & 27 & 100 & \\
\hline $\begin{array}{l}\text { Riwayat ansietas di } \\
\text { keluarga }\end{array}$ & & & 0,001 \\
\hline 1. Ada & 27 & 100 & \\
\hline 2. Tidak & 0 & 0 & \\
\hline Total & 27 & 100 & \\
\hline
\end{tabular}

Tabel 3. Ansietas dan Kemampuan Merubah Pikiran Negatif Pasien Stroke Sebelum Tindakan Keperawatan Ners, Terapi Kognitif dan Psikoedukasi Keluarga

di RS Hermina Jatinegara $(n=27)$

\begin{tabular}{ccccccc}
\hline Variabel & N & Mean & SD & Min & Max & P.Val \\
\hline Ansietas & 2 & 14,8 & 6,765 & 11 & 16 & $\mathbf{0 , 5 4 8}$ \\
& 7 & & & & & \\
\hline $\begin{array}{c}\text { Kemampuan } \\
\text { merubah }\end{array}$ & 2 & 33,7 & 9,217 & 31 & 48 & $\mathbf{0 , 5 1 4}$ \\
pikiran negatif & & & & & & \\
\hline
\end{tabular}

Berdasarkan tabel 3. dapat diketahui bahwa rata- rata tingkat ansietas pasien stroke di RS Hermina Jatinegara sebesar 14,8 menunjukan ansietas sedang dan rata - rata kemampuan pasien stroke merubah Pikiran negatif sebesar 33,7 yang menunjukan kemampuan kurang. 
StrokeSebelum dan SesudahTindakan

Keperawatan Ners, Terapi Kognitif dan

Psikoedukasi Keluargadi RS Hermina Jatinegara

$(n=27)$

\begin{tabular}{ccccccc}
\hline Variabel & $\mathbf{N}$ & $\begin{array}{c}\text { Mean } \\
\text { Sebelum }\end{array}$ & $\begin{array}{c}\text { Mean } \\
\text { Sesudah }\end{array}$ & $\begin{array}{c}\text { Mean } \\
\text { Selisih }\end{array}$ & SD & P.Val \\
\hline Ansietas & 27 & 14,8 & 6,7 & $-8,1$ & 5,250 & $\mathbf{0 , 0 5 1}$
\end{tabular}

Dari tabel 4. menunjukkan ada penurunan rata - rata yang siginifikan pada ansietas dari 14,8 menjadi 6,7 tingkat ansietas normal, skore berkurang 8 poin setelah dilakukan tindakan keperawatan Ners, terapi kognitif dan psikoedukasi keluarga.

Tabel 5.Perubahan kemampuan pasien stroke merubah pikiran negatif sebelum dan sesudah tindakan keperawatan Ners, terapi kognitif dan psikoedukasi keluarga di RS Hermina Jatinegara $(n=27)$
Tabel 4. Perbedaan Ansietas Pasien

Riskesdas (2013) yang meyatakan bahwa hipertensi atau penyakit darah tinggi merupakan penyakit yang paling banyak diderita oleh lansia. Semakin tua usia, tekanan darah cenderung meningkat. Hal ini merupakan proses alami yang terjadi di tubuh. Seperti diketahui bahwa tekanan darah tinggi berbahaya bagi lansia karena dapat menyebabkan penyakit jantung hingga stroke. Santrock, menyebutkan bahwa orang lanjut usia memiliki kemungkinan yang lebih tinggi mengalami kecemasan. Tamher dan Noorkasiani, (2014) juga menyebutkan bahwa masalah psikososial yang paling banyak terjadi pada lansia adalah kesepian, perasaan sedih dan kecemasan.

\begin{tabular}{ccccc}
\hline Variabel & $\mathbf{N}$ & $\begin{array}{c}\text { Mean } \\
\text { Sebelum }\end{array}$ & $\begin{array}{c}\text { Mean } \\
\text { Sesudah }\end{array}$ & $\begin{array}{c}\text { Mean } \\
\text { Selisi }\end{array}$ \\
\hline $\begin{array}{c}\text { Kemampuan } \\
\text { merubah } \\
\text { pikiran } \\
\text { negative }\end{array}$ & 27 & 33,7 & 97,3 & $-63,6$ \\
\hline
\end{tabular}

Dari tabel 5. menunjukkan kemampuan pasien stroke dalam merubah pikiran negatif mengalami perubahan yang signifikan dari 33,7 menjadi 97,3 kemampuan baik, skore meningkat 63 poinsetelah dilakukan tindakan keperawatan Ners, terapi kognitif dan psikoedukasi keluarga.

\section{Pembahasan}

Diketahui bahwa rata-rata usia pasien stroke di RS Hermina Jatinegara berusia 56 tahun. Usia tersebut merupakan kategori lanjut usia, hal ini sesuai dengan hasil ,dßidapatkan bahwa jenis kelamin pasien stroke paling banyak adalah perempuan. Stroke pada perempuan dapat meningkat seiring bertambahnya usia. Perempuan memiliki usia lebih panjang daripada laki laki, sehingga resiko terkena stroke lebih tinggi dibanding laki - laki (Savitri, 2016). Perempuan juga rentan terkena penyakit autoimun dan sejumlah gangguan inflamasi yang dapat menyebabkan kerusakan pembuluh darah atau pembekuan darah yang meningkatkan resiko terkena stroke. Hal ini sesuai dengan hasil Riskesdas (2018) menyatakan bahwa angka kejadian gangguan mental emosional pada perempuan lebih tinggi dibandingkan lakilaki. Sadock dan Sadock (2009) juga 
menyebutkan bahwa angka kejadian gangguan kecemasan pada wanita dua kali lebih banyak daripada pria, hal ini mungkin disebabkan karena wanita memiliki kepribadian yang lebih labil, juga adanya peran hormon yang mempengaruhi kondisi emosi sehingga lebih meluap, mudah cemas dan curiga.

Pendapatan keluarga paling banyak kurang dari 3 juta. Hasil penelitian ini sejalan dengan penelitian Linawati (2009) yang menyatakan bahwa faktor pendapatan keluarga dapat mempengaruhi tingkat kecemasan anggota keluarganya, karena adanya beban moril yang harus di tanggung oleh setiap anggota keluarga untuk dapat memenuhi kebutuhan hidup keluarga. Sumber keuangan meningkatkan pilihan koping seseorang dalam setiap kondisi yang menyebabkan ansietas (Stuart, 2013).

Riwayat ansietas di keluarga paling banyak di miliki pasien. Ansietas dapat disebabkan karena adanya pengaruh faktor genetik dari keluarga. Hasil penelitian ini sejalan dengan penelitian (Brust, 2007) yang menyebutkan bahwa duapertiga sampai tigaperempat pasien terkena ansietas memiliki sekurang kurangnya satu sanak saudara dengan ansietas spesifik tipe yang sama.

Riwayat kecemasan keluarga berpengaruh penting pada kecemasan. Penelitian genetik telah menghasilkan bukti kuat bahwa setidaknya beberapa komponen genetik berkontribusi terhadap perkembangan gangguan kecemasan. Keturunan telah diakui sebagai faktor predisposisi dalam pengembangan gangguan kecemasan. Hampir setengah dari semua pasien dengan gangguan panik memiliki setidaknya satu kerabat dengan gangguan kecemasan (Hadyan,2013).

Pada salah satu penelitian terhadap keluarga yang terkontrol dengan subtipe gangguan kecemasan yang spesifik menunjukkan adanya peningkatan risiko 3 sampai 5 kali lebih besar pada individu yang memiliki riwayat kecemasan dalam keluarga (Merikangas \& Pine, 2002).

Penelitian terhadap saudara kembar telah menunjukkan bahwa genetik memegang peranan penting terhadap gejala dan gangguan kecemasan (Kendler, Neale, \& Heath, 1994).

\section{Ansietas dan kemampuan merubah pikiran negatif pasien stroke sebelum dilakukan tindakan keperawatan Ners, terapi kognitif dan psikoedukasi keluarga}

Pasien stroke mengalami ansietas sedang dan memiliki kemampuan kurang dalam merubah pikiran negatif sebelum dilakukan tindakan keperawatan Ners, terapi kognitif dan psikoedukasi keluarga.

Ansietas merupakan suatu respon normal individu terhadap pertumbuhan, perubahan, pengalaman baru, penemuan identitas dan makna hidup (Sadock, 2009). Ansietas 
adalah rasa takut yang tidak jelas disertai dengan perasaan ketidakpastian, ketidakberdayaan, isolasi, dan ketidakamanan (Stuart, 2013). Ansietas adalah perasaan tidak khas yang disebabkan oleh dugaan akan bahaya atau frustasi yang akan membahayakan rasa aman, keseimbangan atau kehidupan seseorang atau kelompok sosialnya (Videbeck, 2011).

Ansietas pada pasien stroke umumnya di picu dari psikologis pasien yang merasa menyerah terhadap penyakit dan kondisi tubuhnya yang mengalami kecacatan dan kelumpuhan jangka panjang paska stroke, sehingga pasien tidak dapat melakukan aktifitas dan berperan seperti sebelumnya (Adientya dan Handayani, 2012). Rendahnya motivasi dan harapan sembuh penderita serta kurangnya dukungan keluarga sangat berpotensi menimbulkan beban dan berujung pada kecemasan (Kumolohadi, 2001).

Menurut Ormrod, (2004) menyebutkan bahwa terdapat empat aspek yang menyertai kecemasan yaitu aspek kognitif, afektif, fisologis dan perilaku. Aspek kognitif meliputi pikiran yang menakutkan, kekhawatiran dan pikiran - pikiran negatif. Aspek afektif misalnya perasaan tegang, aspek fisiologis meliputi peningkatan denyut jantung, tekanan darah, pernafasan dan proses fisiologis lainnya. Aspek perilaku di tunjukkan melalui perilaku gelisah dan berjalan mondar - mandir.

Hasil penelitian (Rudd, 2007) menyatakan bahwa pasien stroke cenderung memilki rasa takut ketika akan berkomunikasi dengan oranglain. Ketakutannya dapat berupa takut perkataannya tidak dapat dimengerti oleh oranglain, sehingga muncul perasaan malu. Selain itu perubahan fisik karena kelumpuhan menjadi pasien paska stroke kesulitan untuk mengerjakan pekerjaan yang ada di tempat kerjanya, sehingga sebagian memilih untuk berhenti dari pekerjaannya.

\section{Pengaruh tindakan keperawatan Ners, terapi kognitif dan psikoedukasi keluarga terhadap ansietas dan kemampuan pasien stroke merubah pikiran negatif}

Ada penurunan rata - rata yang siginifikan pada ansietas dari 14,8 menjadi 6,7 tingkat ansietas normal, skore berkurang 8 poin setelah dilakukan tindakan keperawatan Ners, terapi kognitif dan psikoedukasi keluarga.

Penelitian yang dilakukan oleh Bektas (2008) menyebutkan bahwa pendidikan kesehatan mempunyai pengaruh yang signifikan terhadap tingkat ansietas. Penelitian lain menyebutkan bahwa pendidikan kesehatan untuk mengatasi ansietas pada remaja di arahkan pada 
berbagai tema seperti managemen stress, pengembangan diri dan relaksasi terpimpin.

Penelitian yang dilakukan oleh Fiandini (2010) menemukan bahwa relaksasi nafas dalam mampu secara efektif menurunkan tingkat ansietas pasien pre operasi di ruang bedah. Hasil tersebut sesuai dengan pernyataan Prawitasari (2002) yang mengungkapkan bahwa teknik relaksasi juga dapat digunakan sebagai keterampilan koping yang aktif dalam kondisi ansietas. Penelitian tentang teknik reduksi ansietas lainnya, diungkapkan pula oleh Mùafiro (2004). Hasil dari penelitian tersebut membuktikan bahwa teknik hipnotik lima jari cukup efektif untuk menurunkan tingkat ansietas pasien kanker leher rahim di ruang kandungan RSU Dr Soetomo Surabaya.

Penurunan tingkat ansietas pada penelitian ini sejalan dengan hasil penelitian yang dilakukan oleh Sauter, dkk. (2009), Otto, dkk. (2004), Prasetyaningrum, (2012), Sarfika, (2012) yang menyebutkan bahwa pemberian terapi kognitif efektif menurunkan tingkat ansietas dan meningkatkan kemampuan merubah pikiran negatif pada pasien stroke.

Hasil penelitian yang dilakukan Chien dan Wong (2007) membuktikan efektifitas psikoedukasi keluaga dalam perkembangan kesehatan psikososial. Penelitian Nurbani (2009) tentang terapi psikoedukasi keluarga dalam mengurangi kecemasan menyebutkan bahwa secara fisiologis ansietas dapat menurun dan dibutuhkan untuk menyelesaikan masalah psikososial akibat penyakit fisik. Penelitian lain yang dilakukan oleh Gonzales, dkk (2010) menyimpulkan bahwa psikoedukasi keluarga efektif untuk pencegahan ekspresi emosi dan beban dalam merawat pasien.

Berdasarkan data tersebut dapat disimpulkan bahwa tindakan keperawatan Ners, terapi kognitif dan psikoedukasi keluarga dapat menurunkan tingkat ansietas dan meningkatkan kemampuan pasien stroke dalam merubah pikiran negatif di RS. Hermina Jatinegara.

\section{Kesimpulan}

Karakteristik pasien stroke di RS Hermina Jatinegara: rata - rata usia 56 tahun, jenis kelamin wanita, penghasilan keluarga <3 juta dan memiliki riwayat ansietas di keluarga. Pasien stroke di RS Hermina jatinegara mengalami ansietas sedang. Tindakan keperawatan Ners, terapi kognitif dan psikoedukasi keluarga menurunkan secara bermakna tingkat ansietaspasien stroke di RS Hermina Jatinegara. Tindakan keperawatan Ners, terapi kognitif dan psikoedukasi keluarga meningkatkan kemampuan pasien stroke merubah pikiran negatif di RS Hermina Jatinegara. 


\section{Saran}

Rumah sakit Hermina Jatinegara hendaknya menjadikan tindakan keperawatan Ners (TND, Distraksi, Hipnotis lima jari dan Spiritual) sebagai standar pelaksanaan dalam menurunkan ansietas pasien stroke. Perawat spesialis keperawatan jiwa hendaknya menjadikan terapi kognitif dan psikoedukasi keluarga sebagai salah satu kompetensi yang dapat dilakukan pada pelayanan kesehatan jiwa khususnya masalah ansietas pasien stroke.Pihak pendidikan tinggi keperawatan hendaknya dapat menggunakan hasil penelitian ini sebagai evidence based dengan lebih mengeksplorasi konsep dan teori keperawatan jiwa dalam mengembangkan teknik penerapan penggabungan terapi kognitif dan psikoedukasi keluarga bagi masalah keperawatan jiwa.Perlu diteliti lebih lanjut tentang karakterisitk lain yang dapat mempengaruhi keberhasilan terapi kognitif dan psikoedukasi keluarga sebagai salah satu bentuk terapi untuk menurunkan ansietas dan meningkatkan kemampuan pasien stroke dalam meubah pikiran negatif. Perlu dilakukannya penelitian kualitatif untuk dapat menggali lebih dalam bagaimana perasaan pasien stroke (klien dan keluarga).

\section{Ucapan Terima kasih}

Penulis mengucapkan terima kasih kepada Direktur Akper Manggala Husada yang telah mengizinkan penelitian dan mahasiswa tingkat I yang bersedia menjadi responden penelitian ini.

\section{Referensi}

Chien, W.T. \& Wong, K.F. (2007). A Family psychoeducation group program forchinese people with schizophrenia in Hong Kong. Psychiatric Services.Arlington. www.proquest.com.pqdauto

Copel,L.C (2007). Psyichiatric and mental health nursing care: nurse's clinical guide.(2 ed ). Philadelphia:Lippincott Williams \& Wilkins

Departemen Kesehatan RI. 2013. Riset Kesehatan Dasar (Riskesdas) 2013. Badan Penelitian dan Pengembangan Kesehatan Kementerian Kesehatan, Depkes RI. Jakarta.

Dochterman, McClskey. (2008). Nursing Intervention Classifications (NIC), 5th edition, St. Louis, Mosby Elsevier.

Elkind, MSV. (2010). Lipid Levels \& Stroke.http://search.proquest.com/do cview/1284213926? accountid=5026 8

Friedman, (2010). Keperawatan keluarga teori dan praktek. Edisi 5. EGC. Jakarta

Gonzales,C et al (2010), Effects of Family Psychoeducation on expressedEmotion and burden of Care in First-Episode psychosis: A prospectiveObservasional Study.. The Spanish Journl of Psychologi, vol 13.www.proquest.com.pqdauto.

Hadyan, N. (2013). "Hubungan antara body mass index (BMI) dengan kecemasan" Universitas Diponegoro 
Junaidi, Iskandar. (2011). Stroke Waspadai Ancamannya. Yogyakarta. ANDI

Keliat, BA,dkk (2005), Modul Basic Course Community Mental health Nursing, Kerjasama FIK UI dan WHO

Mc.Dowell, Ian. (2006). Measuring health: A guide to rating scales and questionnaires, third edition. New York: Oxford University Press

Muttaqin, A. (2008). Buku Ajar Asuhan Keperawatan Klien dengan Gangguan Sistem Persyarafan. Jakarta: Salemba Medika

NANDA. (2008). Nursing diagnoses: definitions dan clasification 20082009. Philadelphia. USA: NANDA International

Nurbani, (2009) Pengaruh Psikoedukasi keluarga terhadap masala psikososial :ansietas dan beban keluarga ( caregiver ) dalam merawat pasien stroke di RS Jakarta pusat Dr.Cipto Mangunkusumo Tesis. Tidak dipublikasikan.

Ormrod, J. E. (2004). Human Learning (4th ed.). New Jersey : PearsonEducation, Inc.

Otto, M.W., Smits, J.A., \& Reese, H.E..(2004). Cognitive Behavioral Therapy for Treatment of Anxiety Disorders.Journal of Clinical of Psychiatry. 65 (5), 34-41.

Prasetyaningrum, S., Fasikhah, S. S., dan Karmiyati, D. (2012). Terapi Kognitif Perilaku untuk Mereduksi Tingkat Kecemasan pada Pasien Pasca Stroke. Fak. Psikologi Universitas Muhammadiyah Malang. Jurnal Intervensi Psikologi. Vol.4 No. 1

Price, S.A. \& Wilson, L.M. (2006). Patofisiologi: Konsep Klinis ProsesProses

Penyakit. 6th Edition. Jakarta: EGC.
Rudd, A., Irwin, P., \& Penhale, B. (2007). Stroke at Yours Fingertips. London: Class Publishing.

Saddock, B.J dan Saddock, V.A (2007). Kaplan and Saddock's synopsis of psychiatry: Behavioral science/clinical psychiatry. 10th Ed. Lippincott William \& Wilkins

Sadock, B.J., \& Sadock, V.A. (2009). Kaplan \& Sadock's Synopsis of Psychiatry: Behavioral Sciences/Clinical Psychiatry,10th Edition. (Philadelphia: LIPPINCOTT WILLIAMS \& WILKINS)

Santrock, J.W. (2012). Life Span Development (Perkembangan masa hidup, Jilid kedua, Penterjemah: Rachmawati dan Kuswanti). Jakarta: Erlangga

Sarfika, Rika. (2012).Pengaruh Terapi Kognitif dan Logoterapi terhadap Depresi, Ansietas, Kemampuan Mengubah Pikiran Negatif dan Kemampuan Memaknai Hidup Klien DM di RSUP Dr. M. Djamil Padang. Tesis. FIK UI. Tidak dipublikasikan.

Sastroasmoro, S, \& Ismael, S,. (2010). Dasar-dasar metodologi penelitian klinis. Edisi ke-3. Jakarta : sagung Seto.

Savitri. (2016). Waspada Stroke pada Wanita. Artikel Kesehatan. Vemale.com

Smeltzer, C.S., \& Bare, R. (2008). Brunner \& suddarth's texbook of medicalsurgicalnursing. (11 th ed). Philadelphia: Lippincott and Wilkins.

Soegiyono. (2011). Metode penelitian kuantitatif dan kualitatif. Bandung: Alfabets 
Stuart, G.W., and Laraia, M.T. (2005). Principles and practice of psyhiatric nursing. (8th ed.). St. Louis : Mosby

Stuart, G.W. (2009). Principles and practice of psyhiatric nursing. (9th ed.). St. Louis : Mosby

Stuart, G. W. \& Sundeen, S. J. (2005). Buku Saku Keperawatan Jiwa. (Edisi 5). Jakarta: Penerbit Buku Kedokteran EGC.

Stuart, G.W., Keliat, B.A. (2013). Prinsip dan Praktik Keperawatan Kesehatan Jiwa Stuart. (Edisi Indonesia). Mosby. Elsevier

Tamher, S. \& Noorkasiani. (2014). Kesehatan Usia Lanjut dengan Pendekatan Asuhan Keperawatan. Jakarta: Salemba Medika.

Tarwoto \& Wartonah. (2003). Kebutuhan dasar manusia dan proses keperawatan. Edisi Pertama. Jakarta : Salemba Medika

Townsend, M.C., (2009). Psychiatric Mental Health Nursing: Concepts of Carein Evidence-Based Practice, (6th ed.). Philadelphia: F.A Davis Company.

Varcolis, E.M. (2006). Foundations of psychiatric mental health nursing. A clinical approach, (5th ed), St. Louis. Elsevier

Varcarolis, E.M. and Halter, M.J., (2010). Foundations of Psychiatric Mental Health Nursing: A Clinical Approach, (6th ed.). St. Louis, Missouri:Saunders Elsevier.

Videbeck, S.L. (2011). Psychiatric mental health nursing. (4rd Ed). Philadhelpia: Lippincott Williams \& Wilkins.

WHO. (2012). Global Burden of Stroke. Available from http $/ /$ who.int/.
Wiwit, S. (2010). Stroke dan Penanganannya. Yogyakarta. Katahari 